\title{
Designing a Sustainable Future for Vietnam
}

\author{
Abraham Sheppard \\ MCRP, Cal Poly (Class of 2013).
}

\begin{abstract}
Through an elective studio, a group of CRP undergraduate and graduate students developed a sustainable planning vision for a coastal area close to the city of Quy Nhon, Vietnam. Inspired by Frank Lloyd Wright's organic design principles, they integrated large scale development proposals to the local context and traditional practices. The author, a participant in the studio, discusses the process and the final proposals.
\end{abstract}

In the Spring quarter of 2013, an elective CRP studio engaged seventeen graduate and undergraduate students from CRP in an urban design project in Vietnam under the supervision of professors Hemalata dandekar and Vicente del Rio. The Organic Design Challenge 2013 was an international, interdisciplinary, visioning project sponsored by Eric Lloyd Wright \& Associates of Malibu for the 3rd Rock Development Company. The CRP class sought to integrate a large-scale project into a traditional coastal community in southeastern Quy Nhon applying organic design and planning principles in the context of a foreign culture and an unfamiliar geographical landscape. The class produced a final report entitled Sustainable Visions for the Future of Vietnam which included three design alternatives. ${ }^{1}$

\section{Organic Design Challege 2013}

In 2011, a similar Organic Design Challenge elicited investigative reports on the city of Quy Nhon from the University of North Carolina at Chapel Hill, the University of Hawaii at Manoa, and Columbia University. The Organic Design Challenge 2013 elicited conceptual ideas and development strategies for the advancement of the private-public Quy Nhon Economic Green Zone Master Planning Project. Besides CRP, the University of Oregon School of Architecture and Taliesen, the Frank Lloyd Wright School of Architecture, participated in the challenge. The goal was to integrate the development of three large coastal sites in a coordinated manner as a foundation for a long-term urban development strategy for Quy Nhon.

According to the 3RockD development company, "the Quy Nhon Economic Green Zone is a test model to showcase how the coordination of urban planning, transportation planning, city infrastructure development, disaster mitigation planning, and municipal policy development can launch a city ... that is economically sound, environmentally sustainable, and culturally reflective" (3RockD, 2012).

\footnotetext{
${ }^{1}$ The final report Sustainable Visions for the Future of Vietnam - Ghenh Rang is available from CRP upon request, or directly from our website at <http://planning.calpoly.edu/content/projects/studio-projects $>$
}

\section{Ghenh Rang and Quy Nhon}

CRP's project site included the district and village of Ghenh Rang within the jurisdiction of the city of Quy Nhon. Located on the south-central coast of Vietnam along the South China Sea, Quy Nhon is the capital of Binh Dinh Province and has a population of around 280,000 . The city's urban fabric is densest in its inland region away from flood-prone, low-lying coastal areas. Quy Nhon has a varied natural landscape that includes lush forested hills, coastal wetlands, broad riverplains, lakes, agricultural lands, aquaculture ponds, wetlands, peninsulas and islands. Aquaculture is a growing segment of the local economy (as it is throughout Vietnam), making the city a large global exporter of farm-raised fish in addition to ocean-caught fish. Sandy beaches stretch 27 miles along the city's eastern coastline. Quy Nhon has a diverse set of natural environments that can be valuable components of a sustainable and economically viable Eco-Urban Region (Spencer, 2011). However, impacts from urban development, typhoons and the loss of coastal mangroves and wetlands have been reducing this rich ecosystem's natural ability to contain and filter excess water, exacerbating flooding in many areas.

Cal Poly students developed plans for the sustainable development of Ghenh Rang, a small coastal ward of approximately 500 acres in southeastern Quy Nhon. Ghenh Rang is physically isolated from Quy Nhon city, bounded by steep hillsides to its north, west and south, and the South China Sea to its east. A single two-lane highway provides the only connection from the main sections of Quy Nhon to the northwest and to other cities to the south. Currently Ghenh Rang has a diverse range of land uses including agriculture, aquaculture, residential neighborhoods, and a small business district. It is home to a small university, a hospital that specialized in dermatology, an historical leper colony, and a park with a monument dedicated to a popular Vietnamese poet. Much of the land area is devoted to rice cultivation and several acres in the southern edge to fish farming. Ghenh Rang is also wellknown for its artisanal industries, including boat building and furniture making - generally small scale factory production. 


\section{Organic Design and Planning Principles}

While Frank Lloyd Wright's organic design principles are clear at the architectural design level, this is not the case at the urban level when one looks at his vision, Broadacre City. City planners and urban historians often dismiss Wright's utopian community visions for being a misguided, environmentally insensitive vision of an "anti-urban" human environment. However, as Eric Lloyd Wright argued during his presentation, his grandfather's vision was rooted in a deep desire for self-sustainable communities built through organic design methods (Wright, 1932). Each of Wright's self-sufficient communities was to be embedded in nature, sustained by its own food production, and enlivened by its own cultural and educational centers

Cal Poly students were challenged to translate Wright's organic design principles into the larger context of community building. According to Frank Lloyd Wright, "in an organic architecture the ground itself determines all features; the climate modifies them; available means limit them; function shapes them" (Wright 1932). His grandson Eric Wright encouraged the class to adopt a foundation based on the nine "sustainable organic design principles" that translate into: simplicity; inside/outside integration; harmony between building and site; nature of materials; character of place; human scale; spirit of building; resonance with nature; and timeless beauty. Inspired by these ideals, the Cal Poly students worked collaboratively to identify the following sustainable design principles as a planning framework that guided the class throughout the design process:

- Respect existing eco-systems

- Develop socially, culturally and environmentally-friendly land-use patterns

- Offer eco-efficient infrastructure and design solutions

- Provide full accessibility

- Maximize existing resources

\section{Development Program}

The client's project brief directed students to provide facilities that support local culture, embrace the natural environment, and encourage a sustainable local economy incorporating elements from both "traditional" and "new" economies. The new facilities are to guide Ghenh Rang to become a global destination for medical tourism, a growing field in Vietnam. Key components of the program included:

- A "smart" hospital and medical tourism campus

- The extension of the Han University campus at the northern edge of Ghenh Rang

- A Green-Tech zone for high-tech industries

- Sustainable agriculture and aquaculture

- A fishing wharf and marina for fishing and boating

- Boat-building and furniture-production facilities

The class engaged in a multifaceted and iterative visioning process. Students also researched international case studies of sustainable design in Southeast Asia which provided an understanding of potential sustainable development practices for Ghenh Rang. The study of existing documentation-such as the investigative reports produced for the 2011 Organic Design Challenge-and a traditional SWOT analysis provided a comprehensive understanding of the location and defined site issues to guide project conceptualization. Based on the five sustainable planning principles discussed above, the teams developed their own visions, goals and objectives to guide them through the design process. Each team produced a set of design ideas and a conceptual diagram designating potential land uses while responding to the site's topography, geography, existing uses, and development potential. After a presentation to the clients, the students refined their concepts and produced detailed development visions including an illustrative site plan and images highlighting key project elements.

Figure 1: Aerial view of the Southern-most part of the city of Quy Nhon, Ghenh Rang and the project site. (source: Google Earth)

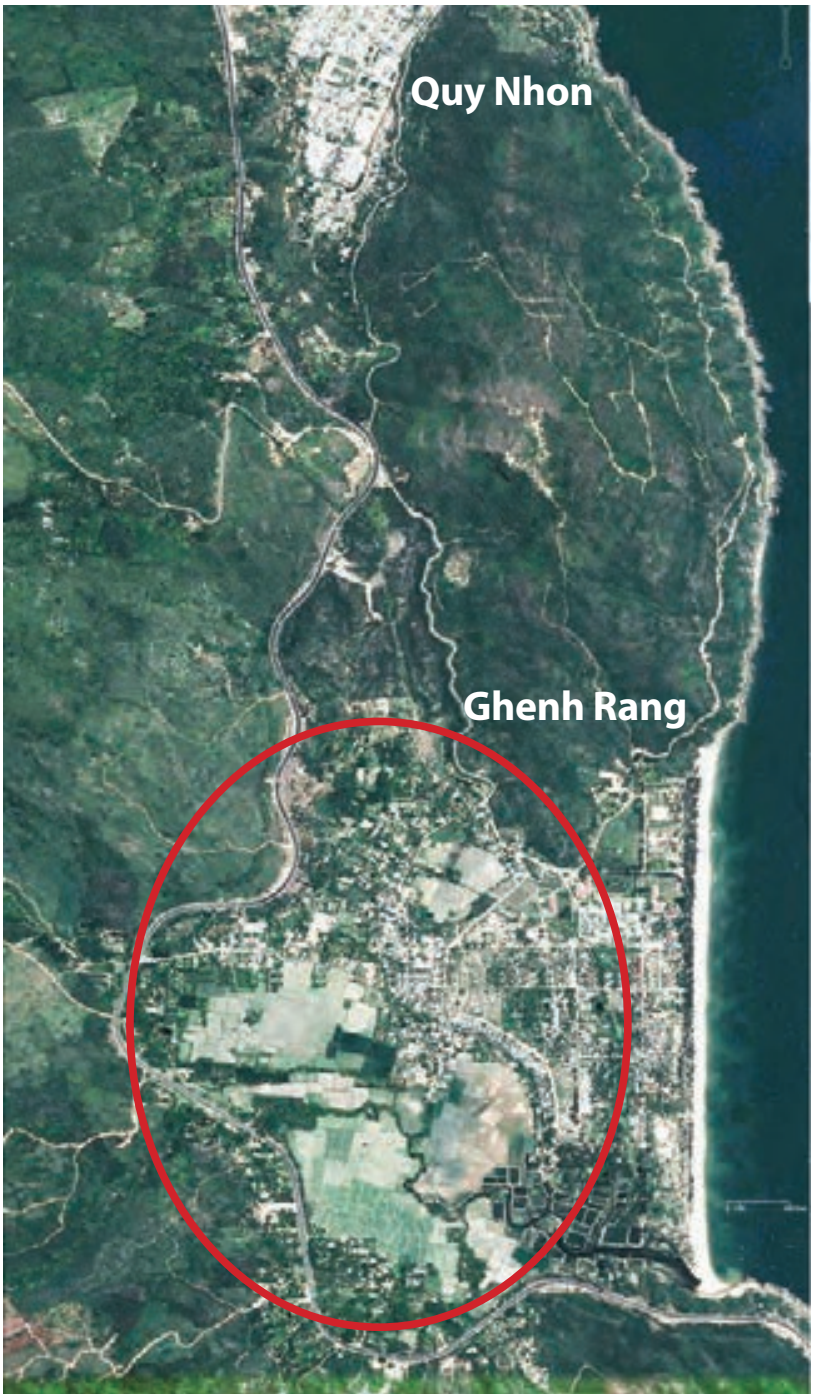



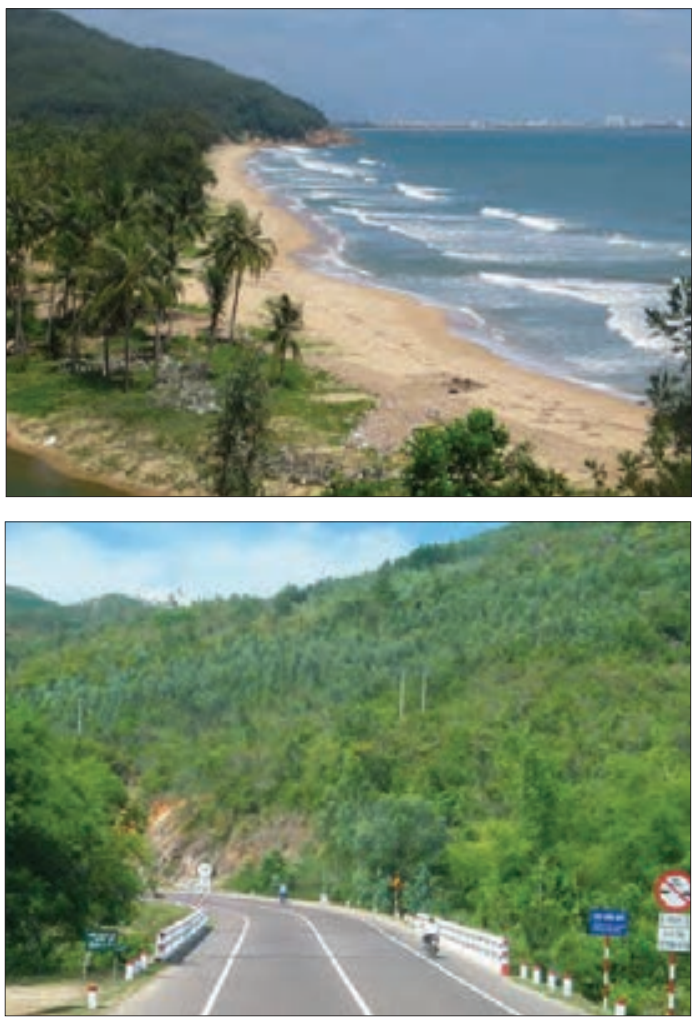

Figures 2 to 5: Images from Ghenh Rang.
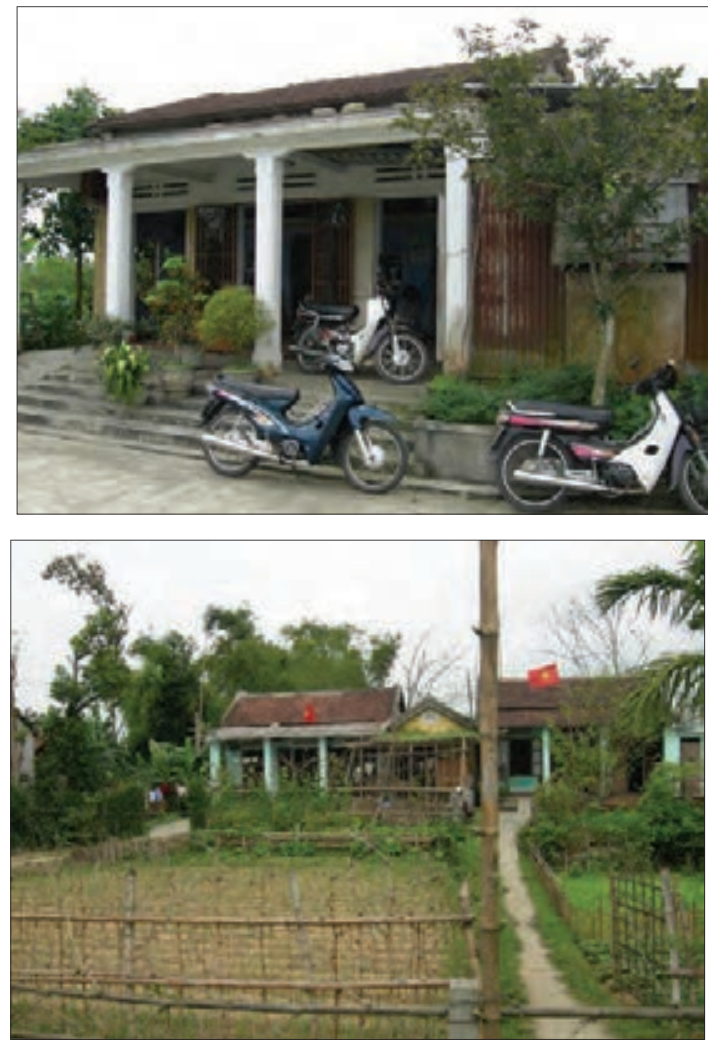

General issues embraced by the class in developing their visions included green building technologies; passive ventilation; building orientation to harness coastal breezes to maximize natural cooling; natural day lighting; water reclamation; rapidly renewable building materials (e.g. bamboo); solar shading; and green roofs. They addressed key environmental concerns involving the health and value of local ecosystems including coastal and freshwater wetlands, coastal mangroves, freshwater rivers, and floodplains. Students were aware that enhancing the coastal mangrove vegetative buffer along Ghenh Rang's coastline would preserve a necessary natural barrier to coastal flooding. They also addressed the need to restore native habitat while also providing dedicated areas for aquaculture, dealing with the problem caused by fish farming pools that had replaced valuable wetlands habitat.

The teams proposed to integrate new development into the existing vernacular built fabric and to enhance, not replace, the traditional urban environment. While developing design solutions and project elements, students were challenged to embrace local land use patterns such as the division of land into long, narrow building plots, and to incorporate local building practices, materials, and scale into new development of varying densities. The teams developed distinct design solutions to provide unique and varied visions for Ghenh Rang to transform it into a vibrant community and a global destination for medical and cultural tourism. Brief descriptions of each team's proposals are as follows:

\section{Team One: Project [RESTORE]}

Elizabeth Brighton, Edith Lopez-Victoria, Kerby Olsen, Thomas Van Pelt, Abraham Sheppard, and Tan Tranngo.

This team sought to integrate modern, service-oriented development into a vernacular built fabric and rich local culture. Project [RESTORE] provides a framework for infill of varying intensities - from preserved and enhanced residential neighborhoods, to beachfront tourist amenities, to a multi-story mixed-use core. The project incorporates three primary catalysts linked by a restored creek along a north-south axis: a university, medical and wellness complex; an active resident- and visitorserving mixed-use core; and a green zone incorporating restored natural habitat and innovative agricultural practices. As shown in the Illustrative Site Plan, several key plan elements present a comprehensive vision for site development:

- An educational and medical campus is composed of an expanded university, "smart" hospital, and a wellness center complex. The health and wellness center, along with an associated university, provides the primary economic driver for development. The hospital-university complex will focus primarily on high-tech medicine and agricultural research.

- A mixed-use core provides local and tourist populations with urban amenities, living accommodations, and active public space. It incorporates infill development in the 
existing core, the reconfiguration of land uses, the integration of natural elements like the creek, and the provision of public open space suitable for cultural ceremonies and social interaction. New buildings will reflect vernacular building typologies. The core is easy to access from the educational facilities, medical and wellness centers, local residential neighborhoods, and other resident/tourist amenities.

- A sustainable environmental/agricultural research center and visitor center provides support to local agricultural and fish farmers to embrace leading sustainable practices. Raised boardwalks will provide access to this valuable natural resource which is located within a restored wetlands habitat area.

- A Cultural Resource Preservation District preserves the historic Quy Hoa Leper Colony, a historic church, and the popular monuments to poet Han Mac Tu and Empress Nam Phuong. The district serves as a central physical and spatial linkage between the Wellness Center, the beachfront, and the downtown core.

- A Creekside Promenade follows a restored creek along a central north-south axis, creating a central spine linking key facilities including the university-medical complex, the mixed-use core, the Cultural Preservation
Area, the wetlands restoration area, and the sustainable agriculture visitor center. Along the restored creek, small-scale vernacular inspired buildings reflect the local mixed-use traditions.

- A Beachside Commercial District, protected from coastal flooding by a restored vegetative buffer, provides active mixed-use for both tourism and local economic practices including fishing and carpentry. The district integrates tourist uses, including hotels and restaurants, into a local mixed-use neighborhood.

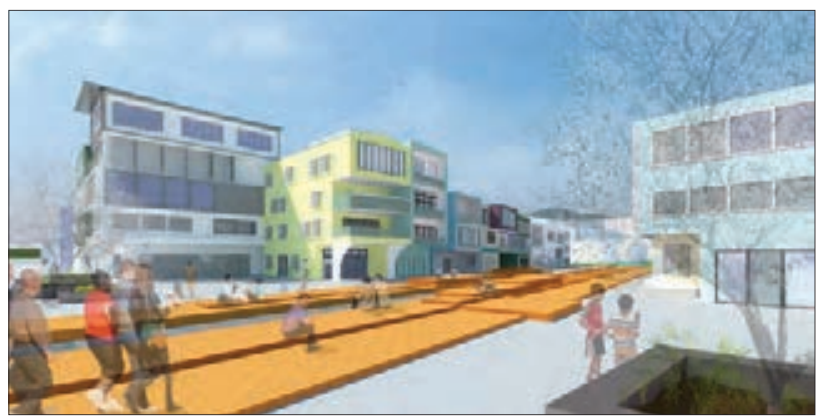

Figures 6 to 8: Project [RESTORE] : mixed-use development along the shoreline (above) and the restored creek running north-south (below), and the illustrative site plan showing the key development elements.
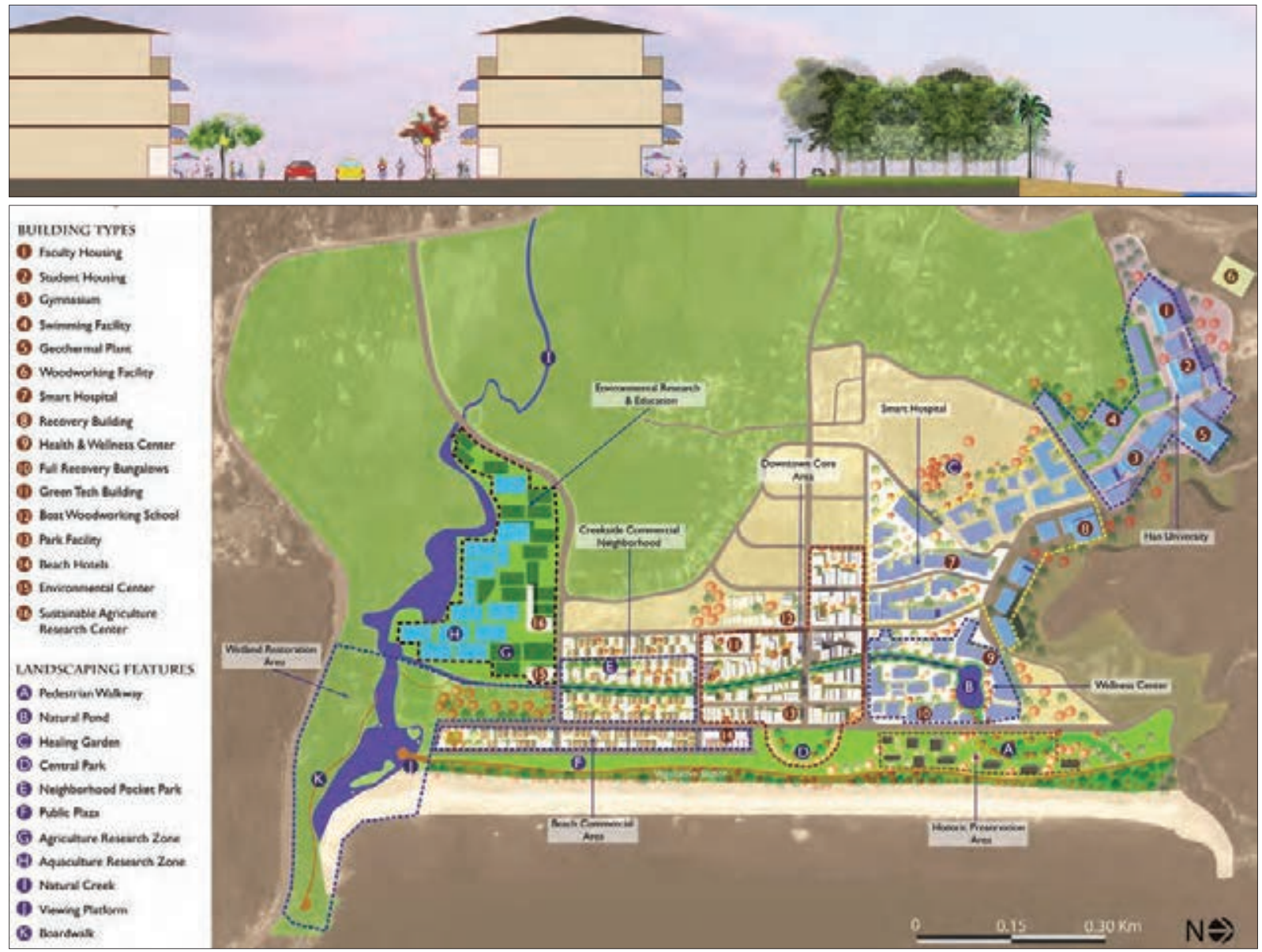


\section{Team Two : The Emerald Queen}

Jenny Ha, Sophia Lai, Matt Orbach, Thomas Park, Stephan Schmidt, Hillary Tung.

The Emerald Queen design team evoked the local cultural significance of the celebrated Empress Nam Phuong, for whom Queen's Beach is named. They propose to use Ghenh Rang's cultural heritage as a central catalyst for their plan that allows for economic development while embracing local culture and a distinct sense of place. Emerald Queen's plan is based on three main economic drivers-medicine, education, and tourismand their design vision includes a main business corridor lined with restaurants and cafes; a cultural center offering a glimpse into local maritime and agricultural history as well as classes in traditional crafts such as wood boat building; and a variety of locally-owned and operated tourist accommodations. Some of this team's key elements are:

- A Downtown Commercial Core located at the intersection of primary transportation routes with a design inspired by traditional Vietnamese ocean side villages. This center provides tourist accommodations, restaurants, and shops. New development respects the local cultural heritage and
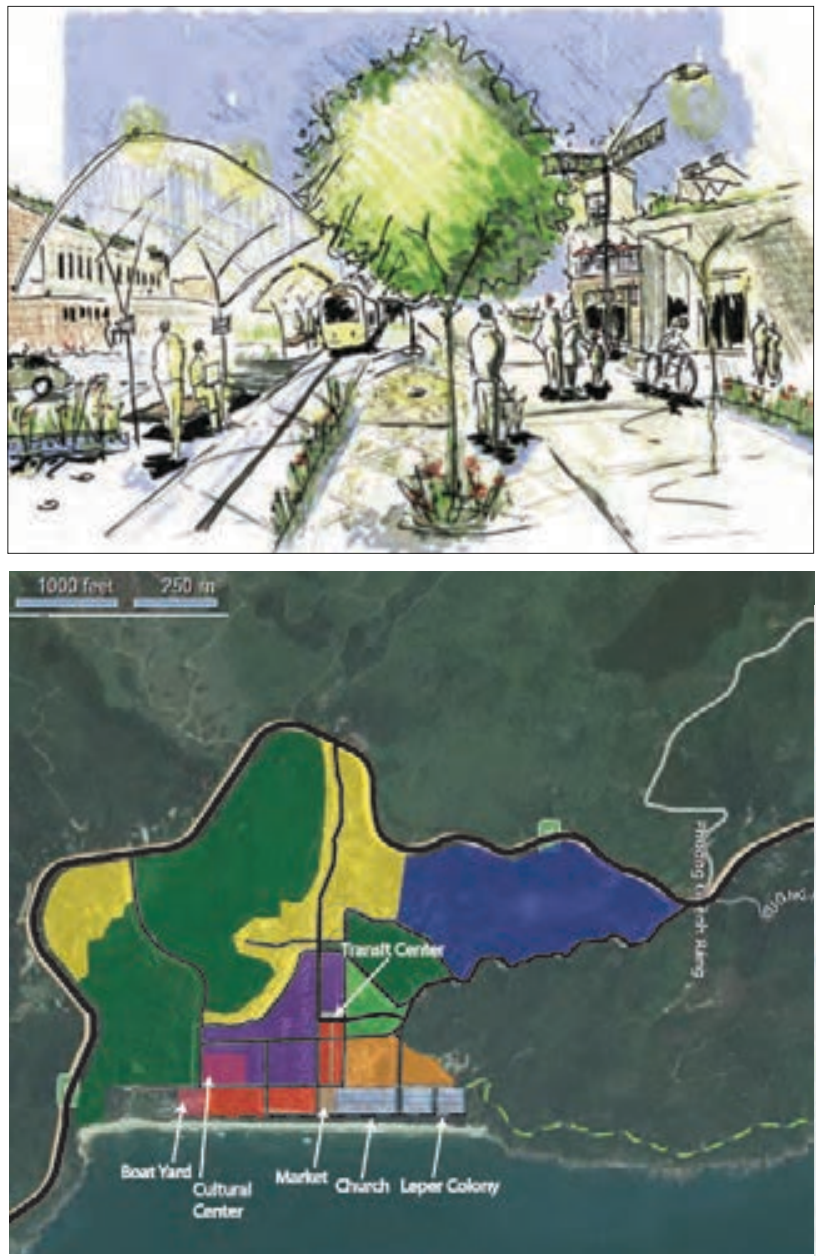

environmentally-sensitive areas while creating a dynamic, mixed-use and accessible core with cafes, hotels, nightlife attractions and a central market.

- A Transit Hub provides multimodal access (bus routes, shuttle services, and taxis) to the main city (North) and the south along the existing highway, and provides connection to Gheng Rang's main points of attraction. Within walking and cycling distance to the commercial core, the transit center allows for decreased traffic on the inner streets.

- A Beachside Local Marketplace occupies a central location and provides flexible space for farmers and artisans. This lively facility serves residents with seafood and fresh produce while tourists are attracted to woodworkers and artisans.

- The Hospital and Rehabilitation Village is a primary economic generator in Ghenh Rang, attracting international visitors. Its location allows for easy access to recuperative natural environments to the north and Queen's Beach to the east. Medical tourists can enjoy the scenic beauty and trails, wide sandy beaches, and rich cultural amenities.

- The proposed University Campus is a regional resource at the northwestern edge of the project area, easily accessed via the primary transportation link to central Quy Nhon. Per the Design Challenge directive, the university will specialize in innovative technology for sustainable agriculture and fishing. Because of its largescale educational and residential buildings, the campus is strategically located at the outskirts of the project area to help retain traditional building scale in the main village.

Figures 9 to 11: The Emerald Queen proposal. Character images of the transit hub and a mixed-use street, and the land-use diagram.
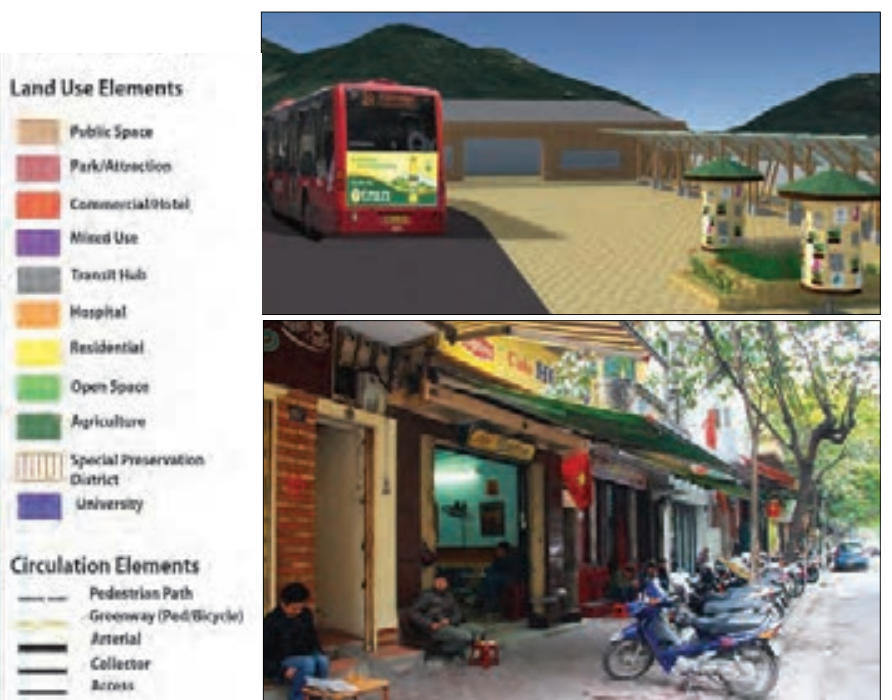


\section{Team Three: Ghenh Rang 2050}

Danielle Althaus, Kyle Bell, Ryan Banuelos, Penelope Legget, Shaun Prestridge.

Team Ghenh Rang 2050 envisions "a community that integrates sustainability through organic design in order to advance the local and regional economy, create opportunities in education, promote a healthy environment, and foster new and existing social connections". The proposal focuses on enhancing the local community by seeking a strong local economy through various scales, from neighborhood-focused marketplaces to international facilities for medicine, education, and tourism. Environmental considerations include the enhancement of a green belt for recreational purposes, the preservation of natural open space within the project site, green corridors, preservation of agricultural land along the floodplain, and a substantial vegetative buffer to project from coastal flooding.

The proposal emphasizes five economic generators for a vibrant local economy: a) education; b) green technology; c) medicine and wellness; d) sustainable agriculture and aquaculture; and e) commerce and tourism. In order to encourage these economic generators, the plan incorporates several key components (see illustrative site plan and renderings) and includes the following:

- A Downtown District with a mixed-use commercial core and a regional transit hub located along an east-west axis with direct access to a beachfront promenade. As the promenade nears the beachfront, varied public open spaces provide social opportunities for both locals and visitors. A transit center provides a multimodal hub for both local and regional transit.
- A Traditional Practices District located at the southern end of the project area will play a vital role in maintaining Ghenh Rang's traditional economy and character. The district enhances the local economy and culture through various elements, including a fish and farmers market, protected harbor, woodworking facilities for boatbuilding and furniture making, an educational center for sustainable agricultural practices, and a community sailing center.

- The university/hospital/sports district incorporates an expanded university campus, a Smart Hospital, and a Sports/Recreational Complex--elements that create an integrated district of related uses. The expanded university is a key factor in promoting Ghenh Rang as an innovator in green technology and sustainable agricultural practices. The Smart Hospital campus provides local health services while also providing a center for medical tourism. The Sports Complex serves the University and Medical campuses and can accommodate large-scale sporting events.

- A pedestrian promenade encircles the central project area, connecting key elements of the plan. Pedestrian routes lead from the downtown core to the beachfront and continue southward to the boat/sailing center and beachside marketplace, and continue inland along a restored creek back toward the downtown district, terminating at the University entrance.

\section{Conclusion}

The 2013 Organic Design Challenge - Sustainable Visions for the Future of Vietnam provided Cal Poly students with a unique op-

Figures 12 to 14: Ghenh Rang 2050: illustrative site plan, beachfront promenade and pier leading to Palm Trees Park and sailing center.
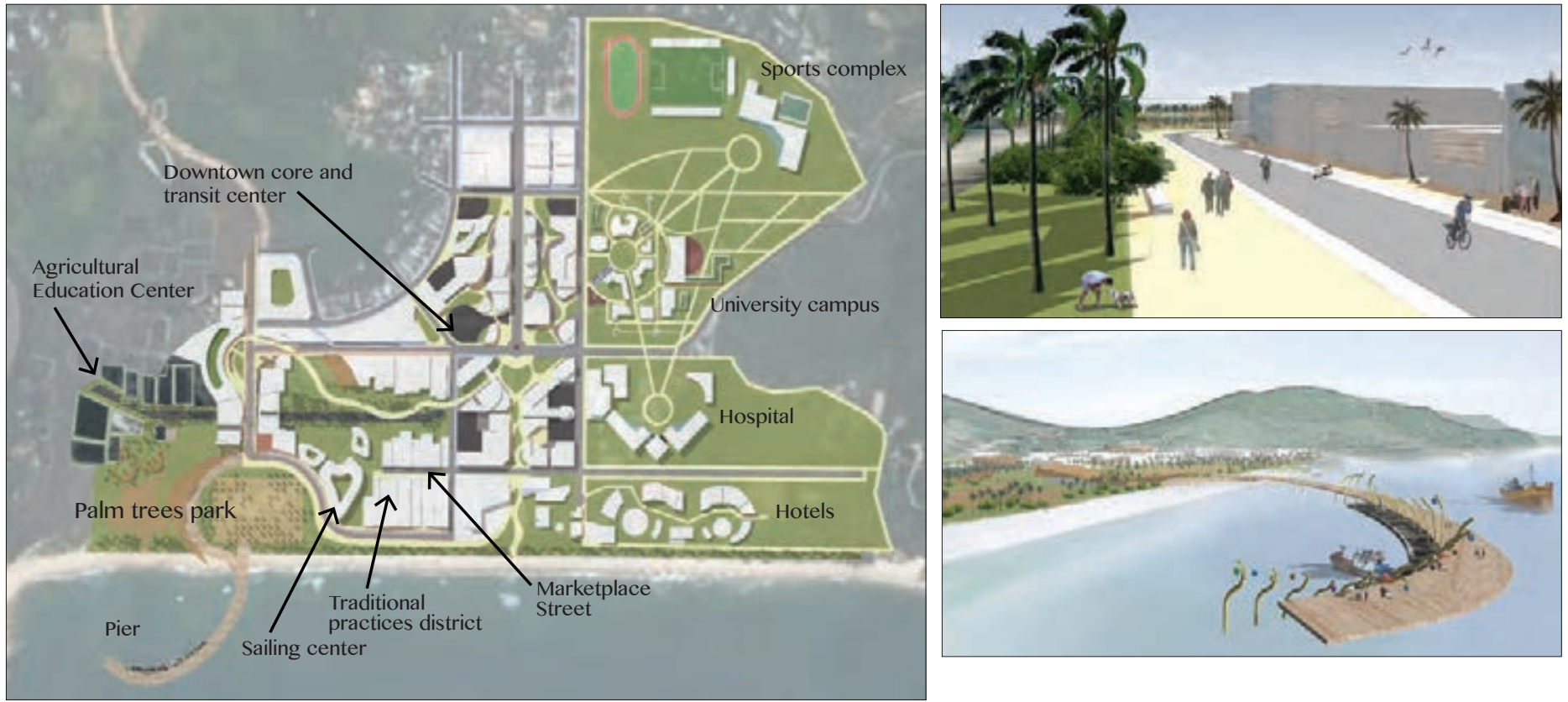
